\title{
SISTEM PENGATURAN PENCAHAYAAN RUANGAN BERBASIS ANDROID PADA RUMAH PINTAR
}

\author{
M. Dwisnanto Putro dan Feisy D.Kambey \\ Jurusan Teknik Elektro, Fakultas Teknik, Universitas Sam Ratulangi Manado \\ *Corresponding author, e-mail : dwisnantoputro@unsrat.ac.id
}

\begin{abstract}
Abstrak-Rumah pintar pada umumnya memperhatikan efesiensi pemakaian energi yang dapat dimaksimalkan dengan memakai pencahayaan alami di siang hari, tata letak lampu penerangan yang tepat, pemakaian peralatan listrik yang hemat energi dan pemakaian lampu hemat energi. Sistem lampu pengaturan penerangan ruangan pada umunya hanya menggunakan prinsip on/off dan tidak praktis untuk dioperasikan, Sistem ini masih memiliki kelemahan yaitu dalam hal efektifitas. Selain dari pada itu faktor kenyamanan dan kebutuhan dalam penerangan ruangan menjadi pengaruh penting untuk kesehatan penglihatan mata manusia. Adapun tujuan dari penelitian ini yaitu membangun sistem pengaturan pencahayaan yang efisien, praktis, sesuai kebutuhan dan dilengkapi dengan optimasi pengaturan pencahayan berdasarkan efesiensi dan standar penerangan ruangan SNI 03-6197-2000. Sistem ini pun dirancang praktis yang dikendalikan secara jarak jauh dengan menggunakan perangkat android smartphone. Penelitian ini bermanfaat bagi masyarakat penghuni rumah tinggal sehingga dapat merasa nyaman, efisien dan praktis untuk mengoperasikan sistem pengaturan pencahayaan pada rumah pintar. Pada perancangannya sistem ini terdiri atas perancangan perangkat keras dan perancangan perangkat lunak perancangan perangkat keras terdiri atas perancangan sensor, aktuator, pengendali dan pengendalian jarak jauh. Sedangkan untuk perancangan perangkat lunak terdiri atas algoritma pemograman cerdas sistem dan pemograman mobile. Pada perancangan pemograman cerdas menggunakan aplikasi arduino IDE sedangkan pada pemograman mobile menggunakan aplikasi APP INVENTOR 2. Kekurangan dari sistem ini adalah dalam penentuan metode nilai parameter, dengan cakupan nilai parameter yang sempit dan respon perubahan intensitas cahaya yang cepat membuat sistem ini tidak stabil.
\end{abstract}

Kata Kunci : Rumah pintar, Pengaturan Pencahayaan Ruangan, Android

\begin{abstract}
Smart Home generally pay attention to energy efficiency can be maximized by using natural lighting during the day, the layout of the lighting, the use of electrical equipment that are energy efficient and use energy-saving lamps. lighting control system should normally only uses the principle on / off and impractical to operate, This system still has the disadvantage of effectiveness.Besides all the convenience factor and needs in lighting the room became an important influence on the health of human eyesight. The purpose of this research is to build an efficient lighting control system, practical, according to the needs and equipped with the optimization of the lighting control based on efficiency and standard of room lightning SNI 03-6197-2000. This system was designed practically controlled remotely using a smartphone android device. This research is helpful to people occupying the residence so that they can feel comfortable, efficient and practical to operate the lighting control system in smart home. In its design of this system consists of hardware design and software design hardware design consist of the design of sensors, actuators, controllers and remote control. While for design of the software consists of intelligent programming algorithms and programming mobile systems. In the design of intelligent programming using arduino IDE application while the mobile programming using the application APP INVENTOR 2. Disadvantages of this system is the method of determining the value parameter, the parameter value ranges are narrow and the fast response changes in light intensity makes this system is not stable.
\end{abstract}

Keywords : Smart Home, Lighting the Room, Android

Copyright $(2016$ JNTE. All rights reserved

\section{PENDAHULUAN}

Rumah merupakan salah satu bangunan yang dijadikan sebagai tempat tinggal manusia dalam jangka waktu tertentu. Fungsi utama rumah digunakan sebagai tempat istirahat setelah lelah beraktivitas dan berkegiatan seharihari. Selebihnya rumah berfungsi sebagai tempat beraktivitas antara anggota keluarga atau teman. Beraneka ragam jenis rumah ada didunia yang 
didesain berdasarkan kebutuhan, gaya dan keinginan dari yang merancang. Sejalan perkembangan teknologi, konsep rumah mulai dipadukan dengan teknologi modern guna membantu manusia merasa nyaman dan praktis untuk melaksanakan kegiatan didalamnya. Konsep seperti ini banyak diminati dan menjadi andalan untuk jenis rumah modern. Rumah pintar (Smart home) merupakan tempat tinggal manusia yang dirancang menggunakan beberapa sistem pendukung elektronik dan komputer secara pintar (bekerja secara otomatis) sesuai kehendak manusia dengan tujuan menjaga tingkat kenyamanan agar manusia dapat beristirahat dan melakukan aktifitas kesehariannya. Konsep rumah pintar merupakan hasil teknologi terapan yang menggabungkan antara rekayasa elektronika, informatika dan arsitertur. Penghuni rumah dapat mengatur semua bagian rumahnya secara otomatis atau dengan menggunakan sistem yang terintegrasi ke smartphone atau gadget lainnya sehingga rumah pintar pun kini menjadi tren dan solusi atas kebutuhan manusia terhadap tempat huni. Rumah pintar kini tersedia di seluruh dunia umumnya memiliki beberapa tugas, fungsi dan kegunaan seperti diantaranya menyalakan dan memadamkan lampu di beberapa ruangan.

Konsep rumah pintar memperhatikan efesiensi pemakaian energi listrik. Dalam desain rumah hemat energi, termasuk didalamnya segala rancang bangunan yang ramah lingkungan, dengan meminimalkan penggunaan energi tidak terbarui dan mengoptimalkan pemanfaatan energi alami. Keterbatasan sumber daya alam membuat konstruksi rumah hemat energi menjadi semakin relevan mulai dari sekarang.

Efisiensi energi bisa dimaksimalkan dengan memakai pencahayaan alami di siang hari, tata letak lampu penerangan yang tepat, pemakaian lampu hemat energi dan pemakaian peralatan listrik yang hemat energi. Rumah pintar termasuk dalam kategori rumah modern yang memiliki tipe desain minimalis yang memanjakan penghuninya. Umumnya tipe rumah seperti ini memiliki ventilasi/instalasi pencahayaan yang banyak dan membiarkan banyak cahaya matahri masuk dalam ruangan. Namun terjadi kelemahan pada saat malam hari dan mendung/hujan, dimana pengaruh cahaya matahari terhadap ruangan menjadi kecil sehingga diperlukan penerangan tambahan seperti lampu untuk kondisi ini.

Sistem pengaturan lampu penerangan ruangan pada umunya hanya menggunakan prinsip on/off, yaitu dengan prinsip menyalakan lampu pada saat ruangan pada kondisi gelap dan mematikan lampu pada saat ruangan pada kondisi terang. Sistem ini masih memiliki kekurangan yaitu dalam hal efektifitas, karena sistem ini tidak menghiraukan pengaruh dan kontribusi dari pencahayaan dari luar yaitu pencahayan matahari. Selain dari pada itu faktor kenyamanan dalam penerangan ruangan menjadi pengaruh penting untuk kesehatan penglihatan manusia. Faktor tersebut dilandasi dengan adanya SNI 03-6197-2000 mengenai standar pencahayaan ruangan pada rumah tinggal yang memuat stardar nilai intensitas (luminan) pencahayan untuk masing-masing ruangan pada rumah tinggal. Oleh karena itu diperlukan pengaturan penerangan ruangan dengan mempertimbangkan faktor kenyamanan dan efesiensi pemakaian energi.

Sistem pengaturan cahaya ruangan dirancang untuk menyesuaikan pencahayaan ruangan berdassarkan kondisi cahaya yang telah dipengaruhi oleh cahaya matahari yang masuk dalam ruangan. Intensitas cahaya menjadi parameter pokok dalam sistem pengaturan ini. Sistem akan mendeteksi terlebih dahulu intensitas cahaya yang ada dalam ruangan yang dihasilkan oleh cahaya matahari, kemudian sistem akan mengatur kebutuhan intensitas cahaya yang diperlukan ruangan tersebut sesuai dengan standar pencahayaan ruangan pada rumah tinggal.

Sistem ini juga dilengkapi dengan pengaturan jarak jauh dengan menggunakan Android smartphone sehingga penghuni secara praktis dapat dioperasikan serta mengatur pencahayaan ruangan secara otomatis ataupun manual.

\section{TINJAUAN PUSTAKA}

Penelitian mengenai pengaturan pencahayaan ruangan menjadi prioritas untuk penghematan energi pada rumah pintar ketika diperhadapkan dengan masalah penggunaan lampu penerangan yang digunakan secara terusmenerus untuk membantu pekerjaan manusia. Ini akan berbanding lusrus dengan pemakaian energi listrik yang semakin lama akan semakin tinggi. Beberapa penelitian mengenai 
pengaturan penerangan dan pencahayaan mengenai penghematan energi seperti dipublikasikan oleh Ryan Masjanuar dkk (2011) dengan menggunakan sensor LDR, PIR dan metode Pengontrol PI mendapatkan hasil persentasi keberhasilan dari penggunaan set point yang ditetapkan yaitu $20 \%$ untuk pagi hari dan $60 \%$ untuk malam hari [1]. Yahya Chusna Arif dkk (2011) dengan menggunakan pengaturan besar sudut penyulutan menggunakan TRIAC (TCA 785) terhadap output lampu LED mendapatkan hasil pemakaian daya yang dapat ditekan sampai dengan 49,375\% untuk set point 90 Lux dan $4,231 \%$ untuk 150 Lux ini disebabkan cahaya luar tidak lebih besar dari cahaya didalam atau pengujian dilakukan di dalam gedung [2]. Heri Kusrianto dkk (2013) melakukan penelitian mengenai sistem pengatur tingkat penerangan ruangan dengan menggunakan mikrokontroler ATMEGA8535 yang dikombinasikan dengan LDR sebagai sensor.

Penelitian ini menggunakan metode logika Fuzzy (mamdani) untuk melakukan proses pengolahan data input yang kemudian menghasilkan tingkatan penerangan dalam suatu ruangan [3]. Perancangan Prototype sistem penerangan otomatis ruangan yang dipengaruhi faktor jendela pernah diteliti oleh Keyza Novianti dkk (2012). Sistem ini berhasil memberikan kondisi keluaran yang stabil pada saat kondisi pencahayaan diluar stabil namun sistem ini belum cukup berhasil ketika kondisi ruangan remang-remang [4]. Sedangkan Fanny Hadisusanto dkk (2012) dengan menggunakan metode algoritma genetika untuk memberikan optimasi terhadap kinerja pencahayaan buatan yang digunakan untuk keperluan efisiensi energi listrik pada ruangan [5].

Tabel 1. Standar Parameter Intensitas Penerangan Cahaya Ruangan [6]

\begin{tabular}{|c|c|}
\hline Jenis Ruangan & Standar (LUX) \\
\hline Ruang Tamu & 250 \\
\hline Ruang Keluarga & 200 \\
\hline Ruang Kerja & 250 \\
\hline Dapur & 200 \\
\hline Toilet & 100 \\
\hline Kamar Tidur & 150 \\
\hline
\end{tabular}

Proses optimasi pada penelitian ini mengacu pada standar pencahayan dan penerangan ruangan yang telah ditetapkan yaitu SNI 03-
6197-2000 . Yang memuat standar penerangan rumah dan bangunan untuk masing-masing jenis ruangan. Tabel 1 menunjukan standarisasi penerangan ruangan tersebut.

Yin Wen Bai et al (2008) mengusulkan desain sistem deteksi dan pengaturan cahaya ruangan secara otomatis dengan menggunakan sensor Pyroelectric inframerah (PIR) dan sensor cahaya sebagai masukan yang kemudian diproses dalam mikroprosessor. Mengambil tema modul pengaturan lampu rumah (HLCM), sistem ini mendeteksi intensitas cahaya dari lingkungan luar dan mempertahankan cahaya tersebut agar stabil dengan melakukan pengaturan berdasrkan jumlah lampu yang terintegrasi dengan sistem jarak jauh menggunakan modul RF [7]. Carlos Machado et al (2009) menggunakan Artificial Neural Networks untuk melakukan pengaturan cahaya ruangan secara otomatis. Dalam penelitian ini sistem komputasi digunakan, dengan memperhatikan tindakan pengguna dan pola dari pengguna yang kemudian dilakukan perekaman. Sistem akan mencoba untuk membebaskan pengguna dari proses penyesuaian pengaturan (manual). Sistem ini mencoba untuk beradaptasi dengan kebiasaan nyata dari masyarakat (otomatis) [8].

Penelitian mengenai rumah pintar telah banyak dilakukan diantaranya oleh Mohamed Mowad et al (2014) yang membuat suatu sistem rumah pintar yang bekerja secara otomatis dengan melakukan pengendalian melalui jarak jauh menggunakan android. empat bidang utama untuk (Smart Home System) SHS yaitu otomatisasi rumah dan pemantauan jarak jauh, pemantauan lingkungan, termasuk kelembaban, suhu, pelacakan kesalahan, manajemen dan akhirnya pemantauan kesehatan. Hasil penelitian ini menunjukkan bahwa sistem dapat diklasifikasikan sebagai sistem yang nyaman, ekonomis dan aman di samping fleksibilitas dan keandalan yang besar [9]. Sedangkan Omar Mahdi et al (2014) melakukan pengaturan peralatan rumah tangga menggunakan gadget elektronik nirkabel melalui teknologi smartphone. Penelitian ini menegaskan antarmuka aplikasi SmartPhone akan memungkinkan pengguna untuk mengontrol perangkat menggunakan aplikasi GPRS. Smartphone dirancang terhubung ke sebuah chip elektronik (Arduino) dan Modus koneksi yang digunakan adalah GPRS [10]. Darwin Sudarma 
(2014) juga menggunakan smartphone dengan aplikasi android untuk melakukan pengaturan lampu pada ruangan rumah. Pengaturan jarak jauh dilakukan dengan menggunakan modul bluetooh. Namun penelitian ini memiliki kelemahan efisiensi dimana pengaturan lampu hanya meggunakan sistem on/off atau mematikan/menyalakan lampu saja [11].

\section{METODOLOGI}

Konsep perancangan alat dalam sistem ini meliputi gambaran diagram blok yang memuat komponen inti dari sistem sampai dengan hubungan komponen sistem dan keterkaitanya dengan input/output sistem keseluruhan. Diagram blok sistem keseluruhan dapat dilihat pada Gambar 1.

Pada perancangan sistem pengaturan pencahayaan ruangan ini terdiri atas perancangan perangkat keras dan perangkat lunak

\subsection{Perancangan Perangkat Keras}

\section{Sensor}

Sensor merupakan suatu instrumen yang mendeteksi kejadian dan gejala fisis seperti cahaya. sensor yang digunakan dalam penelitian ini yaitu menggunakan sensor cahaya LDR yang dihubungkan dengan Resistor $10 \mathrm{~K}$ Ohm sebagai tahanan. LDR merespon ketika terjadi perubahan intensitas cahaya yang ada di sekitar. Sinyal keluaran dari sensor LDR dimasukan pada arduino nano untuk diproses dan dikonversi kedalam bentuk nilai luminan (LUX)

2. Aktuator

Aktuator yang digunakan memutarkan dimmer sebagai peneyesuaian cahaya penerangan menggunakan motor servo.
Dimmer merupakan sebuah alat elektronik yang berfungsi mengatur redup terangnya cahaya lampu dengan cara mekanisme putar. Gerakan aktuator yang memutar dikendalikan dari pengendali arduino nano.

\section{Pengendali}

Pengendali melakukan pemrosesan data dan sinyal yang diberikan oleh sensor dan kemudian memberikan perintah kepada aktuator untuk bergerak dan berputar. Sinyal yang masuk dari sensor berdasarkan deteksi intensitas cahaya yang diterima dari ruangan sekitar yang kemudian sensor tersebut memberikan sinyal dan informasi kepada pengendali. Kemudian pengendali akan melakukan pengolahan informasi yang didalamnya terdapat proses konversi nilai intensitas cahaya dalam satuan lux yang ditampilkan pada LCD Display Nokia 5110, membandingkan nilai parameter dan memberikan perintah/aksi pada motor servo untuk memutar dimmer yang memberikan pengaruh langsung redup dan terangnya lampu pada ruangan rumah pintar. Pada penelitian ini digunakan arduino nano sebagai pengendali sistem. Dengan ukuran memory flash 32KB, SRAM $2 \mathrm{~KB}$ dan EEPROM 1KB.

\section{Bluetooth}

Untuk mengendalikan sistem pencahayaan ruangan ini dari jarak jauh menggunakan media bluetooth, adapun jenis peralatan yang dipakai adalah bluetooth HC-05. Perangkat ini memiliki coverage area kurang lebih dari 10 meter.

Pada Gambar 2 Menunjukkan gambar keseluruhan rangkaian dari sistem ini. Berdasarkan komponen-komponen utama tersebut.

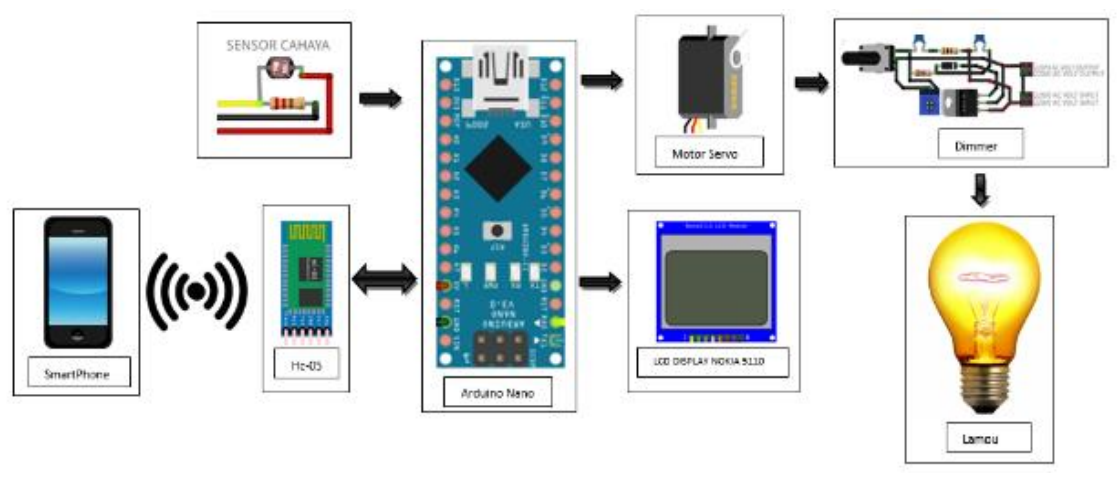

Gambar 1. Diagram Blok Sistem 


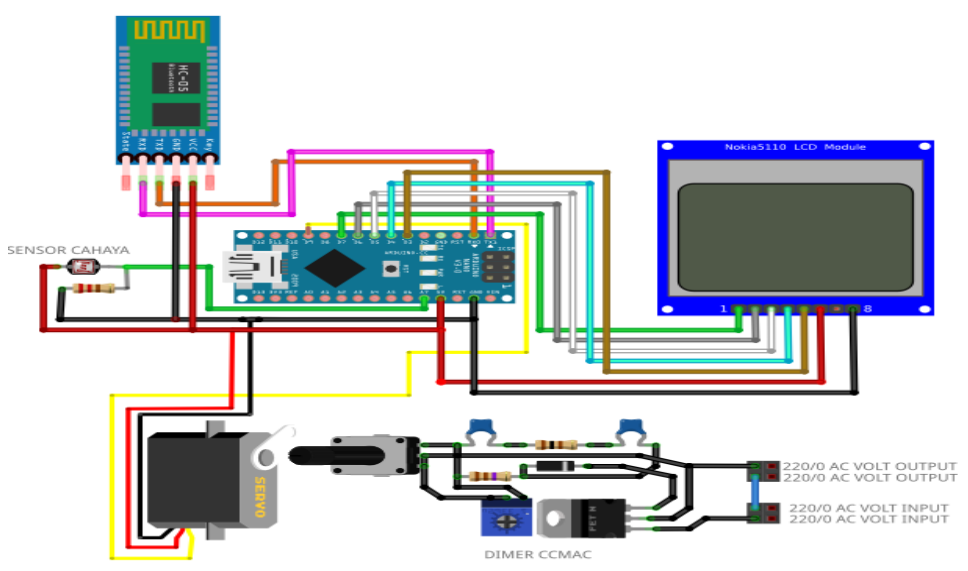

Gambar 2. Wiring Diagram Keseluruhan Sistem

\subsection{Perancangan Perangkat Lunak}

Perancangan perangkat lunak pada sistem ini terdiri atas pemograman mobile dan pemograman sistem cerdas. Pemograman cerdas merupakan suatu tahapan yang dilakukan agar sistem ini dapat bekerja lebih pintar dan sesuai dengan yang diharapkan. Pemograman mobile digunakan untuk merancang suatu aplikasi pada smartphone yang digunakan untuk mengendalikan sistem ini secara otomatis dan manual. Perancangan pemograman mobile pada penelitian ini menggunakan aplikasi APP INVENTOR 2. APP INVENTOR 2 adalah salah satu perangkat lunak sumber terbuka yang menggunakan antarmuka grafis dan memungkinkan pengguna aplikasi ini untuk men-drag and dop objek visual untuk menciptakan aplikasi yang dapat dijalankan pada sistem operasi android. Gambar 3 merupakan contoh block pemograman APP INVENTOR untuk tampilan menu pada sistem pengaturan pencahayaan ruangan.

Sedangkan untuk pemograman sistem cerdas terdiri atas algoritma dan diagram alir yang masing-masing aksi penerangan pencahayaan tergantung pada pembacaan input parameter intensitas cahaya. Gambar 4 merupakan algoritma sistem cerdas yang digunakan pada sistem ini dengan menggunakan IF THEN rule.

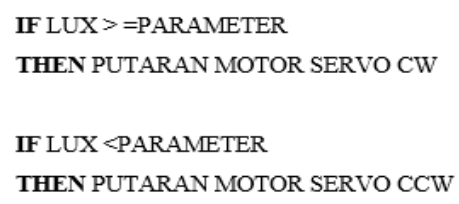

Gambar 4. Algoritma IF THEN rule pada Sistem Pengaturan Pencahayaan Ruangan.
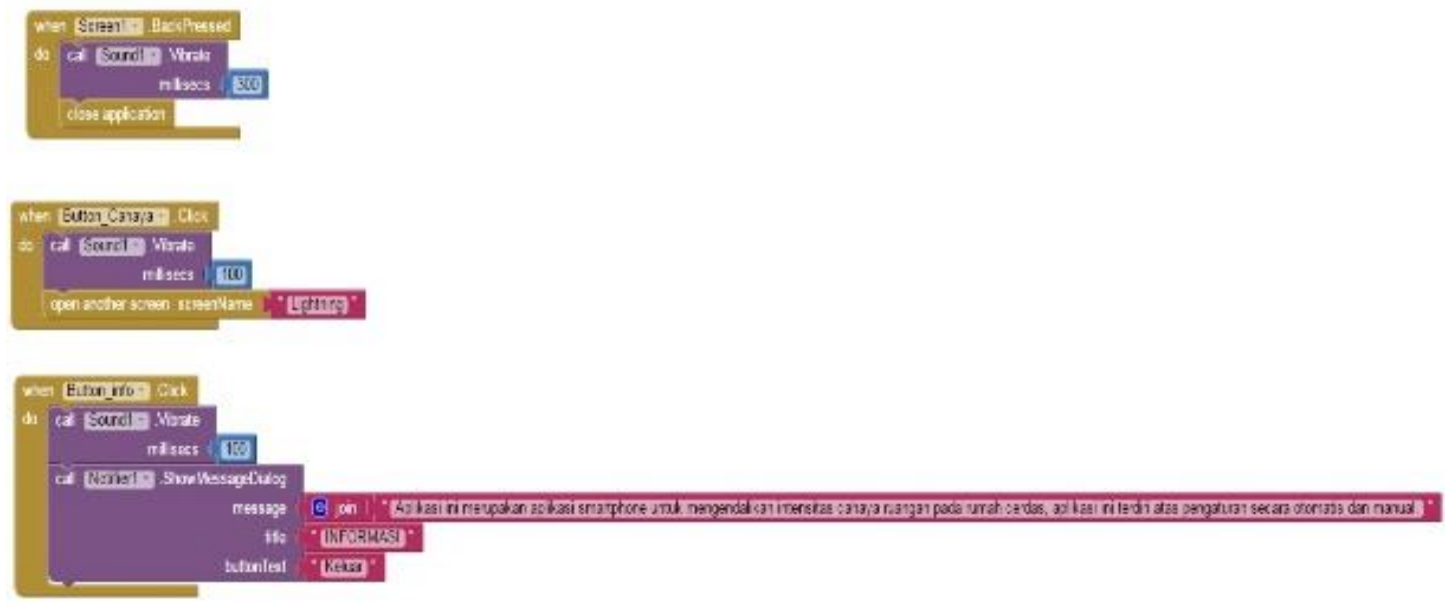

Gambar 3. Block Pemograman APP INVENTOR 
Berdasarkan Aturan tersebut dengan menyesuaikan standar pencahayaan ruangan SNI 03-6197-2000. Maka didapatkan diagram alir pada sistem pengaturan pencahayaan pada ruangan tamu, kerja, keluarga, toilet, dapur dan kamar tidur seperti Gambar 5.

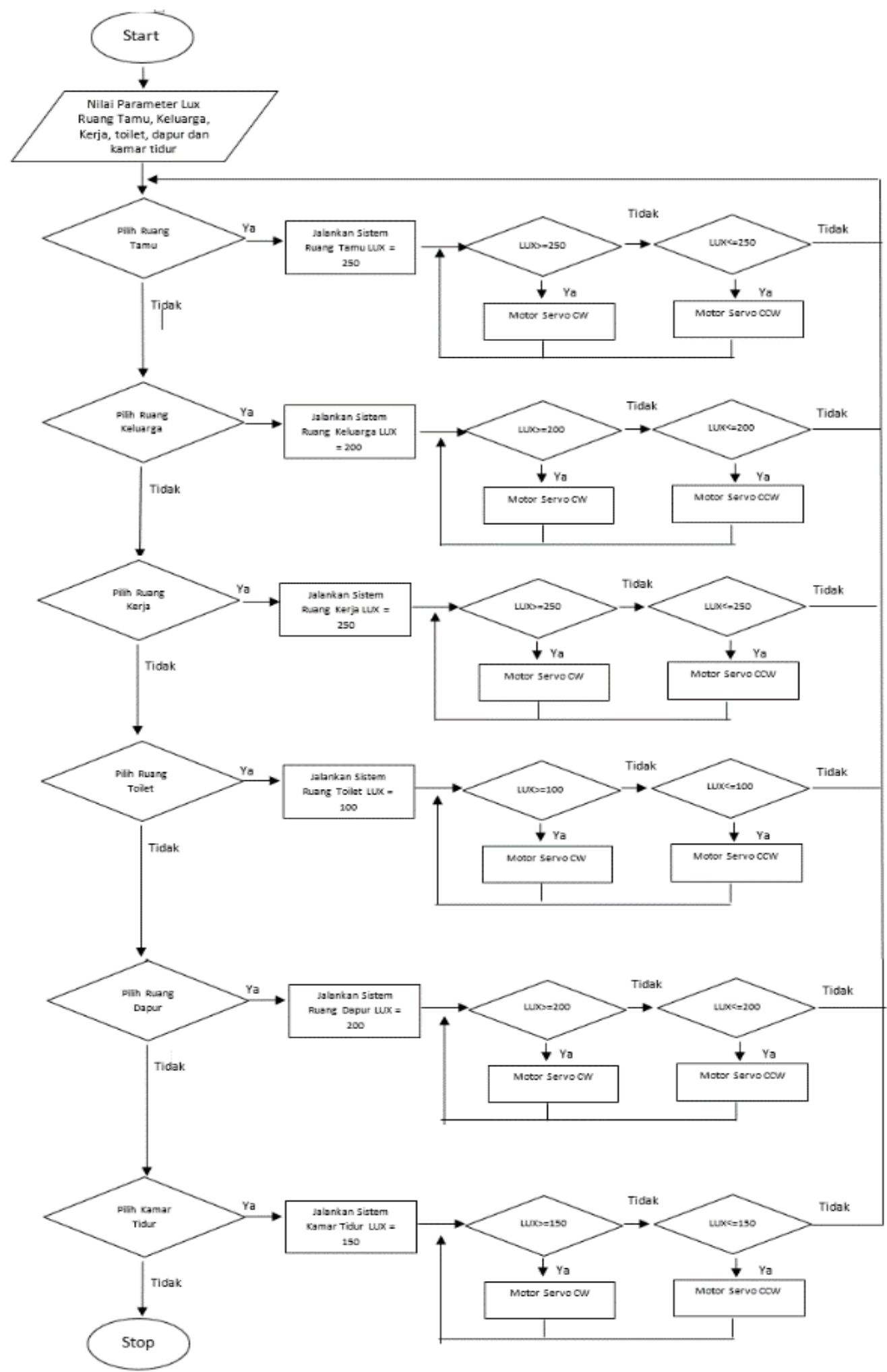

Gambar 5. Diagram Alir Sistem pengaturan Pencahayaan Ruangan 


\section{HASIL DAN PEMBAHASAN}

Adapun hasil dan pembahasan pada penelitian ini terdiri atas diagram use case, diagram activity, dan implementasi tampilan aplikasi android untuk pengaturan pencahaan ruangan. Disamping itu dilakukan juga pengujian terhadap sistem pengaturan yang telah dibuat. Pengujian dilakukan pada sel eksperimen dalam bentuk maket. Maket terbuat dari kertas karton tebal dengan variasi warna putih dan merah. Maket yang dibuat adalah dengan ukuran $50 \mathrm{~cm}$ x $40 \mathrm{~cm}$ x $50 \mathrm{~cm}$ dengan skala 1:20. Maket pada penlitian ini juga merupakan sebagai wadah dari komponen-komponen perangkat keras pada penelitian ini. Prototype maket rumah pintar dibuat dengan bentuk model modern minimalis dengan pertimbangan diperlukannya banyak pengaruh cahaya dari luar (matahari) dengan jumlah jendela adalah 9 buah. Adapun ruangan yang akan dilakukan pengaturan terhadap penerangan cahaya matahari mengambil sampel sebuah ruangan. Gambar 6 merupakan tampilan dari sel eksperimen pada penelitian ini.

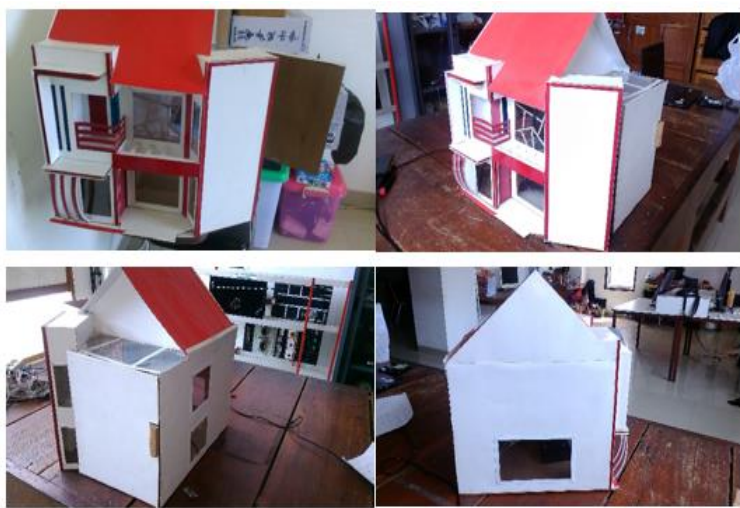

Gambar 6. Sel Eksperimen sistem pengaturan pencahayaan ruangan berbasis android

\subsection{Diagram Use Case}

Diagram Use case pada penelitian ini digunakan untuk menyatakan unit layanan dan fungsi yang tersedia oleh sistem pengaturan pencahayaan ruangan ke user. Gambar 7 merupakan diagram use case aplikasi sistem pengaturan pencahayaan ruangan berbasis android.

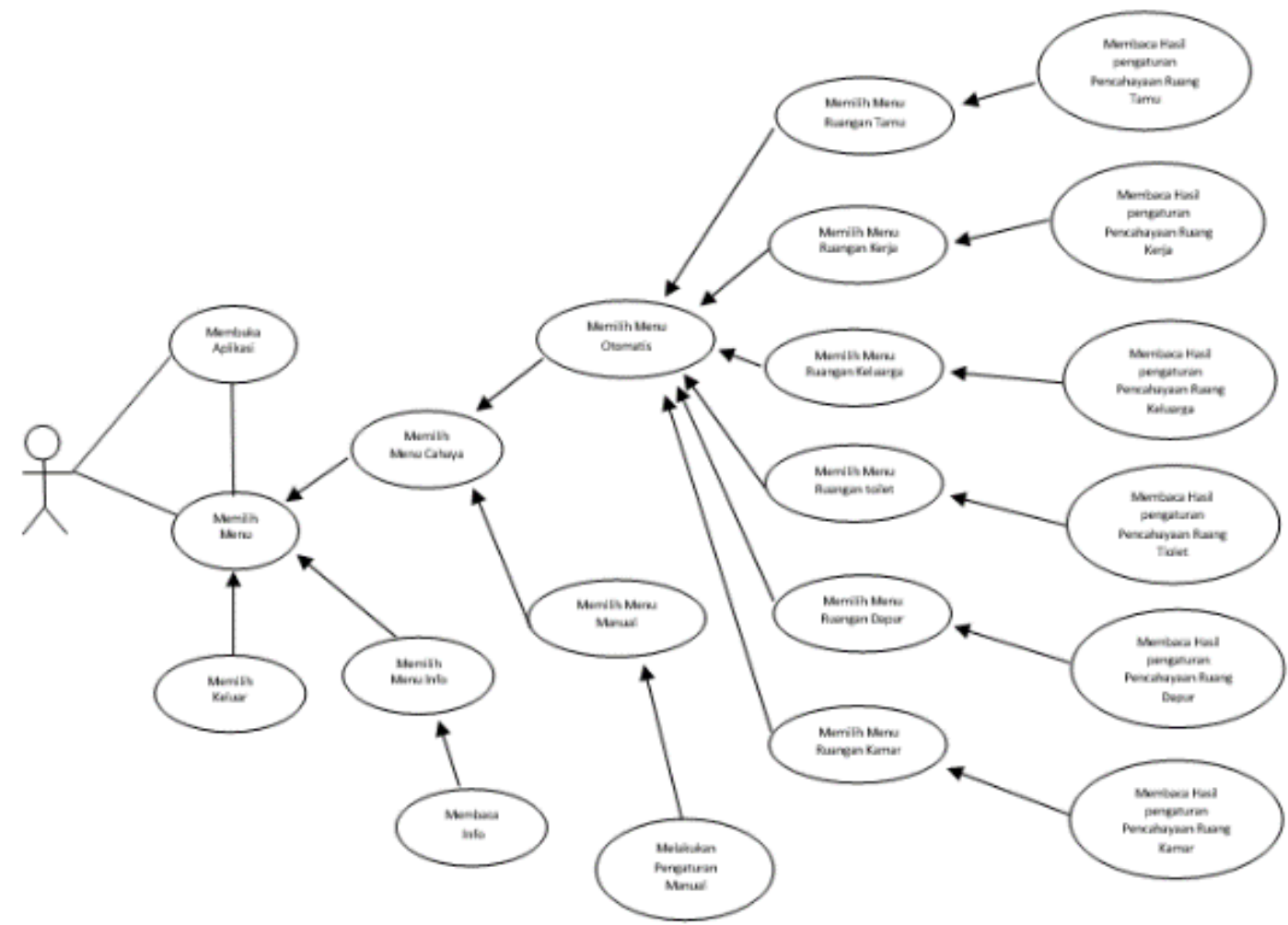

Gambar 7. Use Case Diagram pada aplikasi sistem pencahayaan ruangan berbasis android 


\subsection{Diagram Activity}

Diagram activity pada penelitian ini menggambarkan aliran proses sistem dan aktivitas dari aplikasi sistem pengaturan pencahayaan ruangan berbasis android yang dimulai dari start sampai dengan stop. Gambar 8 merupakan tampilan diagram activity dari aplikasi ini.

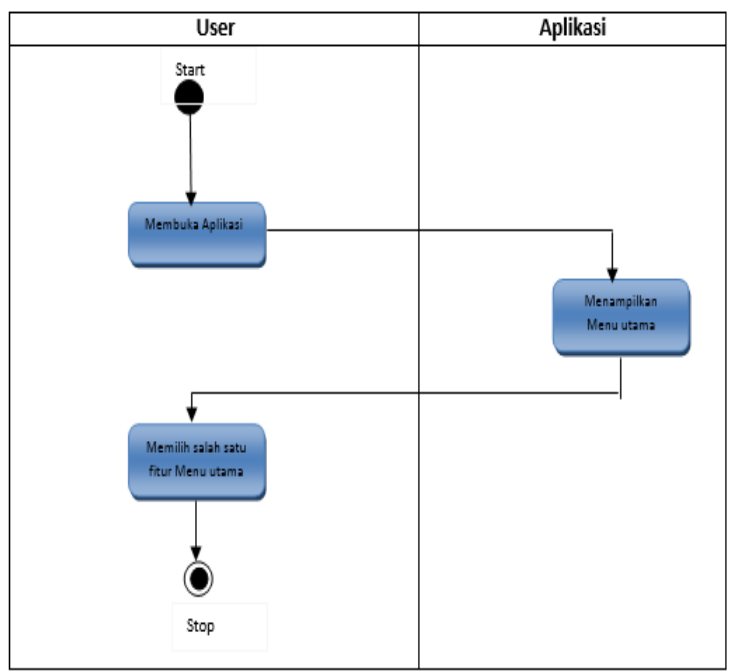

Gambar 8. Diagram Activity pada aplikasi sistem pencahayaan ruangan

\subsection{Implementasi}

Bentuk implementasi dari penelitian ini berupa hasil tampilan aplikasi smartphone berbasis android yang telah dibuat. Aplikasi ini terdiri atas 9 screen, yang didalamnya terdapat menu utama, menu pilihan pencahayaan, menu otomatis, dan menu manual. Untuk menu pencahayaan otomatis dan manual memerlukan pengaturan hubungan/konektivitas dengan perangkat bluetooth HC-05 pada arduino nano.

\subsubsection{Menu Utama}

Pada menu utama memiliki beberapa fitur icon yang merupakan shortcurt untuk membuka fitur aplikasi yang lainya. Fitur ataupun button icon pada tampilan utama aplikasi ini terdiri atas cahaya dan informasi. Button icon cahaya merupakan fitur untuk masuk pada menu pilihan dalam sistem pengaturan pencahayaan, sedangkan button icon informasi dapat dipilih pengguna/user untuk melihat informasi dari aplikasi ini seperti yang ditampilkan pada gambar berikut ini.

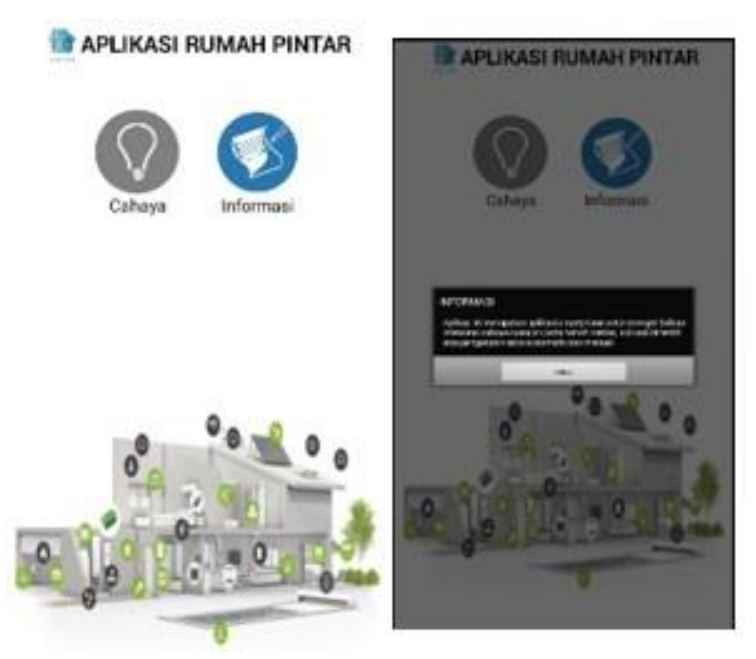

Gambar 9. Tampilan Menu utama

\subsubsection{Menu Pilihan Pencahayaan}

Tampilan menu Pilihan pencahayaan dapat diakses dengan memilih icon cahaya pada menu utama. Saat menu pencahyaan diakses maka pengguna dapat memilih fitur pengaturan pencahyaan secara otomatis ataupun manual.
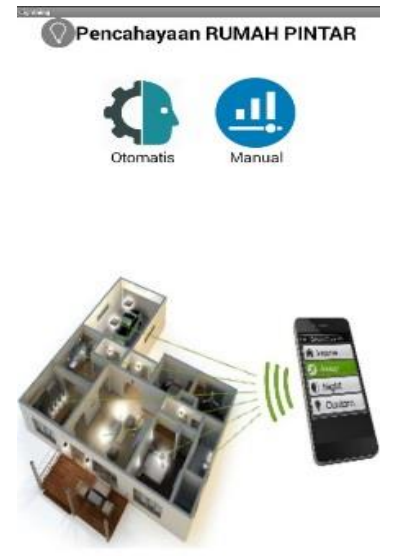

Gambar 10. Tampilan Menu Pilihan Pencahyaan

\subsubsection{Menu Pencahayaan Otomatis}

Screen menu pencahayaan otomatis berisikan pilihan-pilihan pengaturan pencahyaan sesuai kondisi ruangan yang telah ditentukan berdasarkan standar penerangan ruangan SNI 03-6197-2000. Dalam fitur ini ruangan yang dapat dilakukan pengaturan pencahayaan yaitu pada ruangan tamu, keluarga, kerja, toilet dapur dan kamar. Gambar 11 merupakan menu tampilan screen menu pencahyaan otomatis pada penelitian ini. 


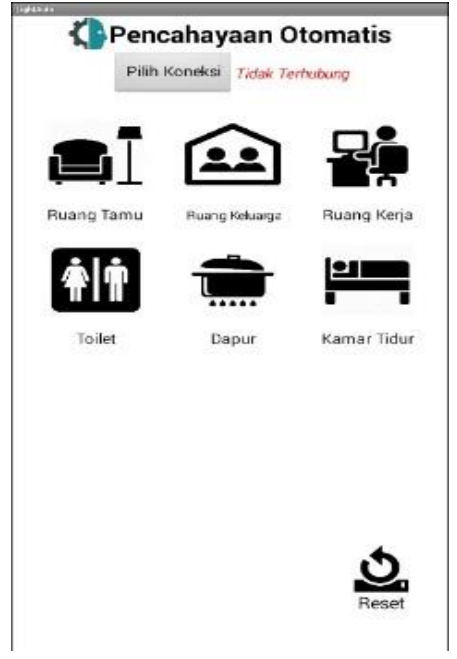

Gambar 11. Tampilan Menu Pencahyaan Otomatis

Pada menu ini juga terdapat pengaturan hubungan dan konektivitas terhadap bluetooth HC-05. Pengaturan ini dilakukan sebelum memilih icon ruangan yang akan dipilih. Pada saat user memilih salah satu button icon pada menu ini maka secara otomatis lampu pada sel eksperimen akan bereaksi dan merespon sesuai kondisi pembacaan sensor yang disinkronisasikan terhadap parameter masingmasing jenis ruangan. Disamping itu pada aplikasi ini juga dapat memantau besarnya intensitas cahaya ruangan (Luminan) pada sel eksperimen untuk masing-masing jenis ruangan. Pada menu ini juga terdapat icon reset yang digunakan untuk melakukan pengaturan kembali terhadap sistem pencahyaan yang sudah dipilih. Gambar 12 merupakan gambar beberapa tampilan pengaturan otomatis pada masingmasing ruangan.

\subsubsection{Menu Pencahayaan Manual}

Screen pada menu ini digunakan untuk melakukan pengaturan pencahayaan rungan secara manual dengan cara menekan empat button icon yang ada pada menu ini. empat button tersebut diantaranya button up untuk menaikan intensitas cahaya lampu, button down untuk menurunkan intensitas cahaya lampu, button max untuk membuat intensitas cahaya lampu menjadi maksimum dan button min untuk membuat intensitas cahaya lampu menjadi minimum.

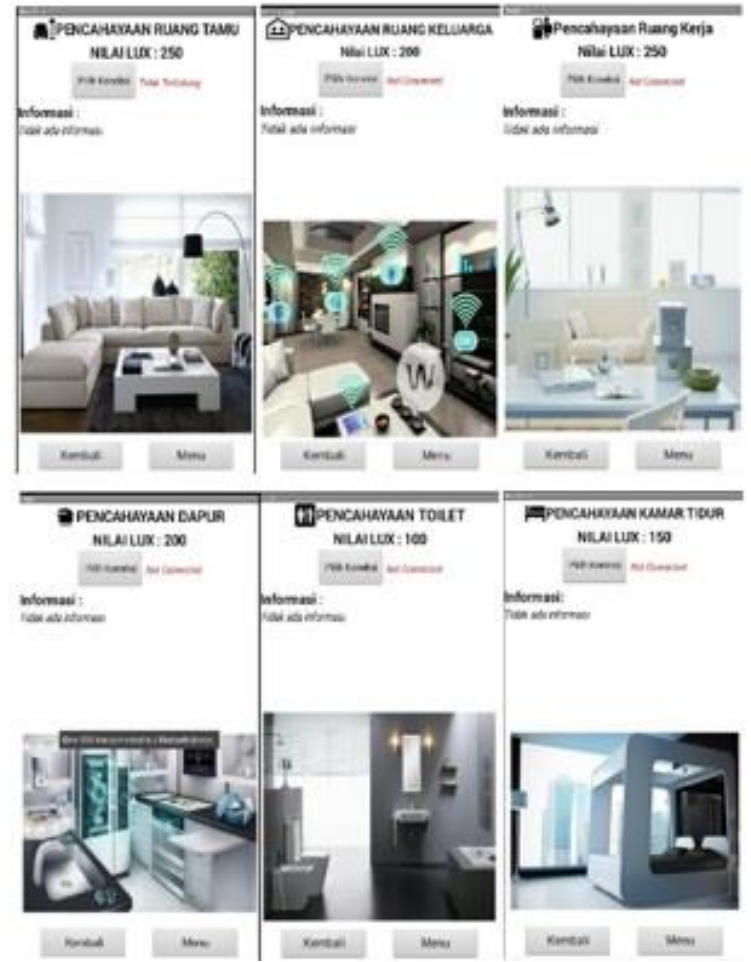

Gambar 12. Tampilan Screen Pencahyaan Otomatis pada masing-masing ruangan

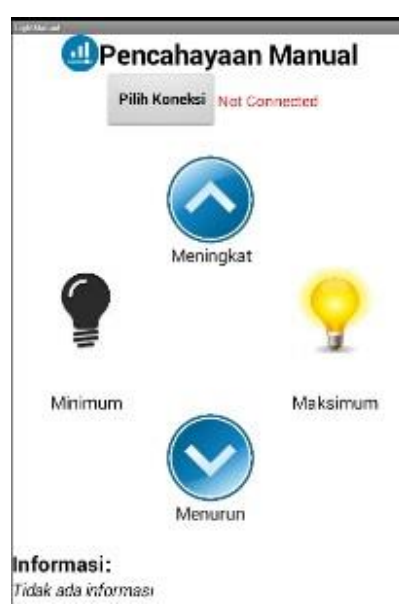

Gambar 13. Tampilan Screen Pencahyaan Manual

\subsection{Pengujian Parameter Sistem}

Pengambilan data diambil langsung melalui sel eksperimen yang telah dibuat. Lampu sebagai pencahayaan buatan yang bertujuan memberikan cahaya tambahan pada ruangan berdasakan input yang dibaca oleh sensor cahaya LDR. Proses pengambilan data dan pengukuran nilai parameter bertujuan untuk proses kalibrasi 
terhadap pembacaan luminan (LUX) pada sistem yang dibuat. Data pengukuran diambil untuk masing-masing ruangan (Ruang tamu, keluarga, kerja, toliet dapur dan kamar tidur) dengan dilakukan pengukuran langsung dengan alat ukur luxmeter dan pengamatan langsung pada LCD Display sistem. Berikut merupakan hasil pengukuran nilai parameter untuk masingmasing jenis ruangan.

Tabel 2. Data pengukuran nilai parameter pada Prototype

\begin{tabular}{|c|c|c|}
\hline $\begin{array}{c}\text { Mode } \\
\text { Ruangan }\end{array}$ & $\begin{array}{c}\text { Lux } \\
\text { (Prototype) }\end{array}$ & $\begin{array}{c}\text { Lux (Alat } \\
\text { Ukur) }\end{array}$ \\
\hline Ruang tamu & 234 & 235 \\
\hline Ruang Keluarga & 194 & 190 \\
\hline Ruang kerja & 250 & 253 \\
\hline Toilet & 85 & 60 \\
\hline Dapur & 194 & 203 \\
\hline Kamar tidur & 147 & 150 \\
\hline
\end{tabular}

Berdasarkan tabel tersebut didapatkan tingkat akurasi tertinggi dalam melakukan kalibrasi pembacaan sensor terdapat pada ruang tamu dengan nilai kesalahan $0,4 \%$ dan ketelitian 99,6\%. Sedangkan tingkat akurasi terrendah terdapat pada toilet yaitu dengan nilai kesalahan sebesar $29,4 \%$ dan ketelitian $70,6 \%$.

\section{KESIMPULAN DAN SARAN}

Hasil dari penelitian ini meliputi sistem perangkat keras yang terdiri atas perangkat sistem pengendali berbasis arduino nano yang secara langsung mengendalikan pencahayaan ruangan dengan menggunakan sensor cahaya dan mekanik dimmer untuk meredupkan dan menerangkan bola lampu. Sedangkan hasil dari sistem perangkat lunak terdiri atas perancangan sistem pemograman cerdas yang dilakukan pada sistem arduino nano dan pemograman mobile dengan hasil tampilan aplikasi smartphone berbasis android ini terdiri atas 9 screen, yang didalamnya terdapat menu utama, menu pilihan pencahayaan, menu otomatis, dan menu manual. untuk Tingkat akurasi tertinggi dalam proses kalibrasi pembacaan sensor pada sistem pengaturan pencahayan ruangan terdapat pada ruang tamu dengan nilai kesalahan $0,4 \%$ dan ketelitian 99,6\%. Sedangkan tingkat akurasi terendah terdapat pada toilet yaitu dengan nilai kesalahan sebesar 29,4\% dan ketelitian 70,6\%.
Untuk saran pengembangan dari penelitian ini yaitu pada penelitian ini masih memiliki kekurangan dalam penentuan metode nilai parameter, dengan cakupan nilai parameter yang sempit dan respon perubahan intensitas cahaya yang cepat membuat sistem ini belum stabil. Sehingga dibutuhkan suatu sistem cerdas seperi logika fuzzy yang dapat menetukan cakupan yang tepat pada sistem ini.

\section{DAFTAR PUSTAKA}

[1] Masjanuar, R., Puspita, E., Taufiqurrahman., Dimmer Lampu Pada Penerangan Ruangan Menggunakan LED Yang Dilengkapi Dengan Otomatisasi dan Emergency, Jurnal Ilmiah Teknik elektronika PENS-ITS, Surabaya, (2011).

[2] Yahya Chusna Arif, Suhariningsih, Lukmanul Hakim, Rancang Bangun Sistem Pengaturan Penerangan Ruangan Berbasis Mikrokontroler (Hardware), Jurnal Teknik Elektro Industri PENS-ITS, Surabaya, (2011).

[3] Heri Candra Kusrianto, Rancang Bangun Sistem Pengatur Tingkat Penerangan Ruangan Berbasis ATMEGA 8535 menggunakan Metode Logika Fuzzy, Tugas Akhir Jurusan Fisika Universitas Diponegoro, Semarang, (2013).

[4] Keyza Novianti, Chairisni Lubis, Tony, Perancangan Prototipe Sistem Penerangan Otomatis Ruangan Berjendel Berdasarkan Intensitas Cahya, Seminar Nasional Teknologi Informasi, (2012).

[5] Fanny Hadisusanto, Yuningtyastuti, Agung Warsito, Optimasi Kinerja Pencahayaan Buatan Untuk Efisisensi Pemakaian Energi Listrik pada Ruangan Dengan Metode Algoritma Genetika, Makalah Seminar Tugas Akhir Teknik Elektro Universitas Diponegoro, Semarang, (2012).

[6] Badan Standarisasi Nasional, SNI 036197-2000 (Konservasi Energi Pada Sistem Pencahayan), Hal 4, (2000).

[7] Ying-Wen Bai, Automatic Room Light Intensity Detection and Control Using a Microprocessor and Light Sensor, Consumer Electronics, IEEE Transactions on (Volume:54, Issue: 3 ), (2008).

[8] Carlos Machado, Jose Mendes, Automatic Light Control in Domotics 
Using Artificial Neural Networks, International Journal of Computer System Science and Engineering 4:2, (2009).

[9] Mohamed Mowad, Ahmed Fathy, Ahmed Hafez, Smart Home Automated Control System Using Android Application And Microcontroller, International Journal of Scientific \& Engineering Research, Volume 5, Issue 5, May-2014 ISSN 22295518, (2014).

[10] Omar Mahdi, Bhavya Alankar, Wireless Controlling Of Remote Electrical Device Using Android Smartphone, IOSR Journal of Computer Engineering (IOSR-JCE) eISSN: 2278-0661, p- ISSN: 22788727Volume 16, Issue 3, Ver. I, (2014).

[11] Darwin Sudarma, Rancang Bangun Kendali Lampu On/Off dengan Smartphone Adnroid Via Bluetooth, Jurnal Teknik Elketro Universitas Tanjungpura, Pontianak, (2014).

\section{Biodata Penulis}

M. Dwisnanto Putro, adalah seorang pengajar di Jurusan Teknik Elektro Universitas Sam Ratulangi sejak tahun 2012. 